\title{
Energy demand and economic consequences of transport policy
}

\author{
J. B. Alam $\cdot$ Z. Wadud \\ J. B. Alam · J. W. Polak
}

Received: 28 October 2011/Revised: 9 March 2012/ Accepted: 28 November 2012/Published online: 29 March 2013

(C) Islamic Azad University (IAU) 2013

\begin{abstract}
Transport sector is a major consumer of energy. Concern of energy scarcity and price fluctuations enhanced significance of transport sector in national planning. This paper analyses energy demand for transport services in Bangladesh for different policy scenarios. Aggregate transport demand model is integrated into Long-range Energy Alternatives Planning model to forecast consequences of transport policy on energy demand and economy. Demand for imported energy for transport sector is observed to increase from 1.7 million ton of oil equivalent (Mtoe) in 2005 to 11.8 Mtoe in 2030 for business-as-usual scenario. In increased fuel price scenario, cost of importing fuel for transport sector is projected to increase from 1.37 to more than $14.9 \%$ of Gross Domestic Product during the same period. Country's energy demand may be reduced by 2 and 4 Mtoe in 2030 by improvement of waterway and railway, respectively. Moreover, by using compressed natural gas in motor vehicles cost of importing fuel may be reduced by US $\$ 5$ billion annually in 2030 and a further
\end{abstract}

\footnotetext{
J. B. Alam ( $\square)$

Department of Civil Engineering, King Abdulaziz University, P.O. Box 80204, Jeddah 21589, Saudi Arabia

e-mail: malam@kau.edu.sa

Z. Wadud

Department of Civil Engineering, Bangladesh University

of Engineering and Technology, Dhaka, Bangladesh

J. B. Alam

Department of Civil and Environmental Engineering, Shahjalal

University of Science and Technology, Sylhet, Bangladesh

J. W. Polak

Department of Civil and Environmental Engineering,

Imperial College London, London, UK
}

reduction of transport sector energy demand by $9 \%$ can be achieved through eliminating subsidy on fuel.

Keywords Economic impact · Energy demand model . Passenger and freight transport - Sustainable transport options

\section{Introduction}

Transport is an essential prerequisite for economic activities. Facilitating transport services require provision of infrastructure and supply of energy. Globally, a significant share of energy supply is consumed by transport sector. Interaction between transport service provision and energy requirement is well recognized by the researchers and decision makers (European Commission 2004; DTI 2001). Transport sector energy requirement depends on infrastructural forms of transport system, which often evolves within the context of national transport policy. Generally, structure of transport system can vary widely ranging from road and personal vehicle-based scheme to public transport systems that include rail and non-motorized transport. Transport system of Bangladesh has evolved dynamically during last few decades, and it currently relies on extensive roadway network. Reliance on roadway resulted in ever increasing demand on imported gasoline. Due to rapid increase of fuel price in recent years this dependency, in turn, generates considerable liability on national economy. Such a situation has evolved from lack of awareness to pursue long-term policy toward sustainable transport. Considering growing of demand for transport services with increased energy scarcity and price concerns, provision for transport facilities in future will be a challenging responsibility for the government. Although a few studies focused 
on overall energy scenario of the country, clearly there exists lack of research on disaggregate sector level policy implications of energy demand (NEP 2004; REP 2008; Miah et al. 2010; Wadud et al. 2011). This paper deals with impacts of transport policies on energy and economy in Bangladesh.

In the paper, two initial sections discuss energy sector and transport policy of Bangladesh. The third section illustrates framework for analysis of interaction between transport and energy demand in the country, which is then extended to analyze its economic implications. In the subsequent sections, four alternate policy options are analyzed. The paper concludes with policy recommendations which include assessing implications of enhanced use of natural gas in transport sector and increased use of alternate modes like rail and waterway. The paper also illustrates the impact of reducing subsidy on fuel. Research presented in the paper focuses on analyzing interaction of transport scenario and policy with energy demand in Bangladesh. It also presents analysis of consequent economic impacts resulting from fuel demand and price escalation for the period between 2005 and 2030.

\section{Materials and methods}

Global energy demand and price scenario

About $85 \%$ of world's total energy supply comes from fossil fuel, of which nearly $40 \%$ comes from petroleum and another $21 \%$ from natural gas (Balat and Ayar 2005; EIA 2007). World oil demand is expected to grow from 80 million barrels (bbl) in 2003 to 98 million barrels in 2015 and 118 million barrels in 2030, despite high increase in price (EIA 2006). Demand has been increasing rapidly particularly in developing and emerging economies, which include China, India and Brazil. Rezki and Bennard (2002) suggest that global oil demand will be 107 million barrels per day in 2030 and two-thirds of the increase in demand will be caused by China and other developing countries.
Oil price in international market will continue to increase due to increased demand and geo-political interferences.

During the last few years, oil price fluctuated significantly. Starting from $\$ 24 / \mathrm{bbl}$ in early 2000 , oil price reached $\$ 145 / \mathrm{bbl}$ in August 2008. Although market price of oil reduced slightly to $\$ 110$ recently, it has doubled since 2004 and quadrupled since 2002 (Feiler 2006). Analysts suggest that oil price will remain high although short-term price fluctuations will continue to be part of emerging scenarios (UN-ESCAP 2005). In the context of increasing energy demand and price, developing countries like Bangladesh face precarious future.

Overview of economy and energy scenario in Bangladesh

Bangladesh is a densely populated country with a population of 150 million and annual Gross Domestic Product (GDP) of US $\$ 89$ billion at the current market price. Although economy of Bangladesh is primarily based on agriculture, contribution of other sectors including industry, trade and services are gradually increasing. At present agriculture contributes about $21 \%$ to national economy which is followed by industry, services and transport with 18,10 , and $9 \%$, respectively (BBS 2009). Figure 1 summarizes general pattern of economic development in Bangladesh (at constant 1994 market price). It can be seen that service sector is expanding faster than average GDP growth rate of $5.5 \%$ per annum. Since service sector activities are more disaggregated in nature and generate higher transportation demand, growth in transportation demand will possibly be higher than the forecasts based on aggregate GDP growth trend (NCHRP 1999).

At present, aggregate energy demand in Bangladesh is about 950 trillion British Thermal Unit (BTU) with an average growth rate of $5.2 \%$ per year. Of the total energy, $40 \%$ comes from biomass burning and the rest from fossil fuels which include natural gas, oil and coal. Natural gas alone constitutes $70 \%$ of fossil fuel supply (Faruque et al. 2002). In 2009, Bangladesh imported 3.6 million ton of
Fig. 1 General pattern of economic development in Bangladesh

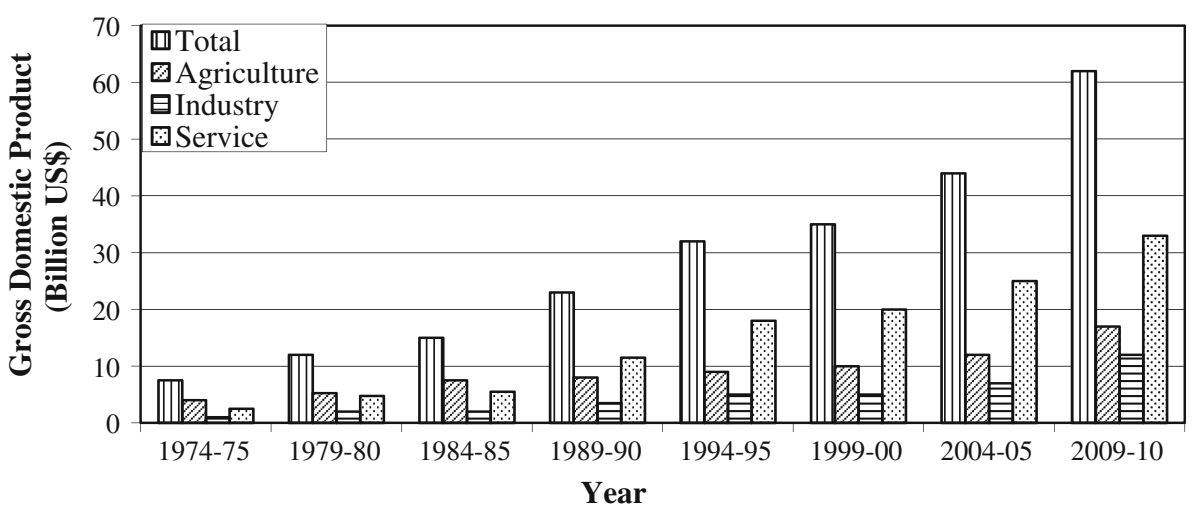


Table 1 Type wise consumption of energy during 1999-2010 (BBS 2009)

\begin{tabular}{llrrrr}
\hline Item & Unit & Years & & & \\
\cline { 3 - 6 } & & 1999 & 2002 & 2005 & 2008 \\
\hline Electricity & Million Kilowatt Hour (MKWH) & 11,352 & 12,638 & 14,670 & 17,727 \\
Gas & Million Cubic Meters (MMCM) & 8,780 & 1,0276 & 1,1325 & 1,2346 \\
Petroleum & Thousand Metric Ton (Thou. MT) & 3,232 & 3,313 & 3,215 & 3,499 \\
Coal & Thousand Metric Ton (Thou. MT) & 92 & 66 & 1,4117 \\
\hline
\end{tabular}

Table 2 Investment in transportation sector $(\%)$

\begin{tabular}{lllcc}
\hline Years & $\begin{array}{l}\text { Transportation sector } \\
\text { investment as \% of annual } \\
\text { development budget }\end{array}$ & \multicolumn{2}{l}{ Investment as \% of transportation investment } \\
\cline { 3 - 5 } & Roadway & Railway & Waterway \\
\hline $1974-75$ & 11.56 & 32.4 & 7.3 & 40.3 \\
$1979-80$ & 13.79 & 42.0 & 30.6 & 27.4 \\
$1984-85$ & 11.59 & 35.9 & 36.3 & 27.8 \\
$1989-90$ & 12.01 & 49.6 & 29.9 & 20.5 \\
$1994-95$ & 16.91 & 78.3 & 14.7 & 7.0 \\
$1999-00$ & 18.81 & 88.0 & 9.0 & 3.0 \\
$2004-05$ & 19.00 & 88.6 & 8.0 & 3.4 \\
$2009-10$ & 19.20 & 88.9 & 7.8 & 3.3 \\
\hline
\end{tabular}

petroleum fuel costing US $\$ 1.99$ billion, which was about $1.96 \%$ of the country's GDP and $16 \%$ of current account balance. During last three decades, use of natural gas has been increasing at a rate of $8.4 \%$ per year. In future, coal may also play a significant role as primary energy source of the country (IIFC 2006). Consumption of energy in Bangladesh grew at $7.6 \%$ rate in recent years (Table 1 ), which is higher than average GDP growth. Of the total energy consumption (excluding biomass) transport sector consumes about $10.2 \%$ costing more than US $\$ 770$ million. Total energy consumption in transport sector was 48 trillion BTU in 2003. As transport services largely rely on imported fossil fuel, increased fuel price implies further liability on national economy.

Motivated by political judgment, traditionally governments in Bangladesh provide substantial subsidy on fuel price in internal market. With continued increase in price of crude oil and petroleum products in international market, government's response has been very slow and resulted in total subsidy of $\$ 170.5$ and $\$ 445.4$ million in 2004 and 2005, respectively. Since 2008 government has been gradually increasing prices of petroleum products to reduce subsidy.

Transportation policy of Bangladesh

During the last three decades transportation has been one of the highest priority investment sectors for government and donor agencies (Land Transport Policy of Bangladesh
2006). During this period, about US $\$ 40$ billion was invested in transport sector of the country. Road sector in particular attracted major share of this, far exceeding investments in other modes (Table 2). Currently, about $90 \%$ of transport sector budgetary allocation is used for road sector development. Consequently, roadway inventory and number of registered vehicles demonstrated rapidly increasing trend (Economic Review of Bangladesh 2009). Table 3 shows that average growth rate in the number of registered vehicles is $8 \%$. Sharp rise in the number of fourstroke three-wheelers in 2001 resulted from government's decision to replace two-stroke three-wheelers by compressed natural gas (CNG)-based four-stroke three-wheelers in Dhaka. Figures 2 and 3 show that road networks currently serve about $80 \%$ of passenger travel (passenger$\mathrm{km}$ ) and $65 \%$ of freight movement (ton-km) in the country. As the total transportation demand increased from 17 billion passenger-km and 2.6 billion ton-km in 1974 to 150 billion passenger-km and 28 billion ton-km in 2007, rapid modal shift toward road is more apparent in aggregate terms.

Because of indiscriminate investment in road sector, volume of country's road network increased from 3,764 in 1971 to $272,612 \mathrm{~km}$ in 2008 with $51,233 \mathrm{~km}$ of paved road. Moreover, National Land Transport Policy envisages further enhancement of road network (Land Transport Policy of Bangladesh 2006). Government also approved plans to construct elevated expressway and flyovers overlooking mass transit, railways, and waterways. 
Table 3 Number of registered vehicles in Bangladesh

\begin{tabular}{|c|c|c|c|c|c|}
\hline Type of vehicle & 1995 & 1999 & 2003 & 2008 & Growth rate $(\%)$ \\
\hline Car/taxi & 61,962 & 94,042 & 126,171 & 177,273 & 9 \\
\hline Jeep/microbus & 29,911 & 38,748 & 49,190 & 64,324 & 6 \\
\hline Bus & 12,724 & 13,939 & 15,543 & 17,663 & 1 \\
\hline Minibus & 11,092 & 12,999 & 15,185 & 19,045 & 3 \\
\hline Truck & 31,706 & 41,008 & 51,087 & 66,069 & 6 \\
\hline A rick/tempo & 50,539 & 75,637 & 97,169 & 107,262 & 7 \\
\hline Motorcycle & 175,088 & 231,785 & 318,418 & 428,665 & 7 \\
\hline Other (incl. CNG 3-Wh.) & 7,255 & 14,151 & 58,303 & 88,654 & - \\
\hline Total & 380,277 & 522,309 & 731,066 & 968,955 & 8 \\
\hline
\end{tabular}

Fig. 2 Demand for passenger transportation in Bangladesh

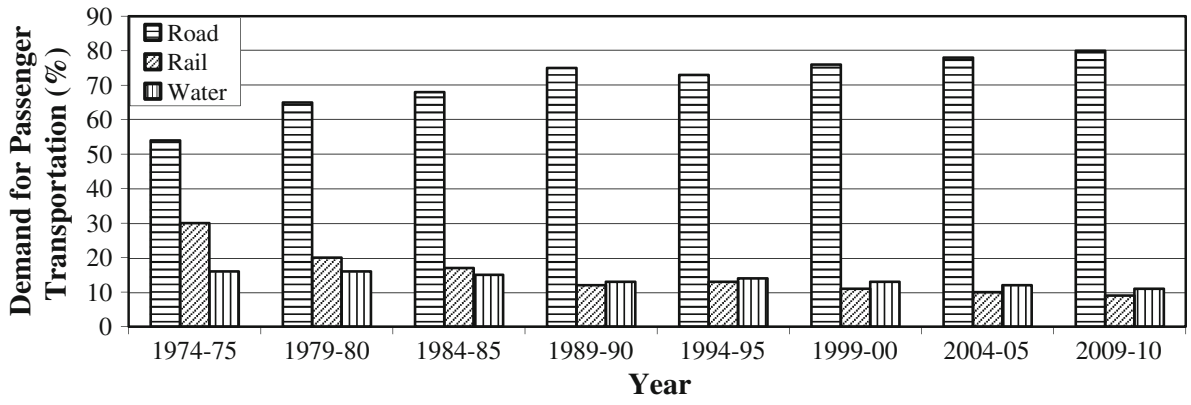

Fig. 3 Demand for freight transportation in Bangladesh

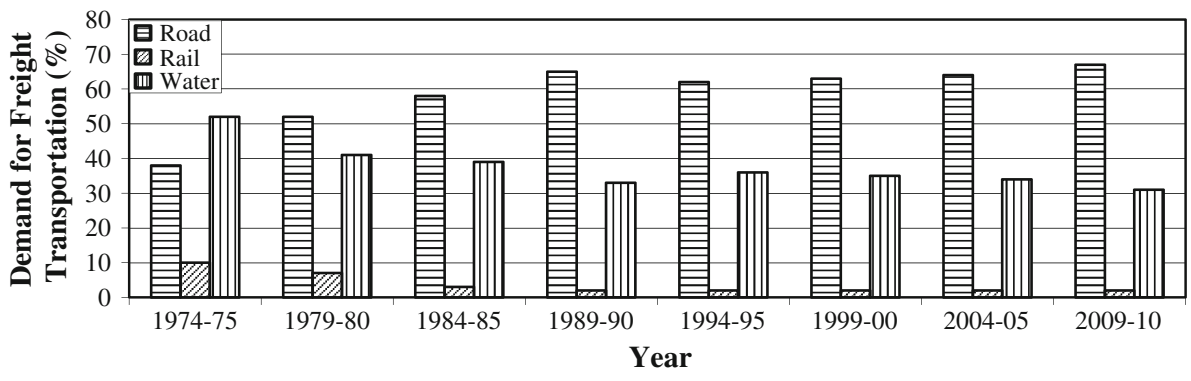

Over reliance on road mode resulted in energy hungry transport system. As energy demand in transport sector is primarily satisfied by imported fuel, government's policy bias toward road transportation and ever increasing fuel price is creating burgeoning burden on national economy. Following sections illustrates the extent of economic consequence in relation to increasing transport demand and fuel price.

\section{Analysis framework}

For analyzing transport sector energy demand, aggregate travel demand model is incorporated into energy analysis framework using Long-range Energy Alternatives Planning (LEAP) model developed by Stockholm Environmental Institute (LEAP 2006). It provides integrated energy accounting framework facilitating assessment of country's energy demand for alternative scenarios of demand and supply parameters. LEAP is based on end-use-driven scenario analysis using four levels of hierarchy, which include sectors, sub-sectors, end-use, and devices. Also, it enables demand-supply equilibrium analysis. However, this study focuses only on demand side to estimate transport energy usage in different scenarios. Implementation of LEAP follows the framework described by Bose (1996) and Dhakal (2003). Aggregate travel demand models were calibrated to forecast annual passenger and freight transport demand and constituted transport sector level scenario in LEAP framework. Distribution of demand among road, rail, and water formed sub-sector level scenario and allocation of demand among alternative means within particular modes provided end-use level scenario. Technology and vehicle per passenger (inverse of occupancy rate) organized device level aggregation scenario. The final stage required energy intensity information, provided in the form of fuel economy $(1 / \mathrm{km})$ for various alternatives, to estimate energy requirement at 
Table 4 Parameters for energy demand analysis [Source: Road User Cost, RHD (2005)]

\begin{tabular}{lllll}
\hline & Vehicle type & Annual usage $(\mathrm{km})$ & Occupancy/loading rate & Fuel efficiency $(\mathrm{km} / \mathrm{l})$ \\
\hline Passenger & Bus & 120,000 & 45 (passenger/vehicle) & 2.80 \\
& Minibus & 56,000 & 30 (passenger/vehicle) & 3.23 \\
& Microbus & 31,000 & 4.2 (passenger/vehicle) & 7.64 \\
& Jeep & 42,000 & 2.3 (passenger/vehicle) & 4.99 \\
& Car & 24,000 & 1.6 (passenger/vehicle) & 9.82 \\
& Taxi & 24,000 & 1.8 (passenger/vehicle) & 9.82 \\
& Auto-rickshaw & 52,000 & 1.1 (passenger/vehicle) & 42.00 \\
Freight & Motor cycle & 14,000 & 1.1 (passenger/vehicle) & 52.5 \\
& Truck & 36,000 & 11 (ton/vehicle) & 2.62 \\
\hline
\end{tabular}

Fig. 4 Comparison between reported and estimated road sector energy demand

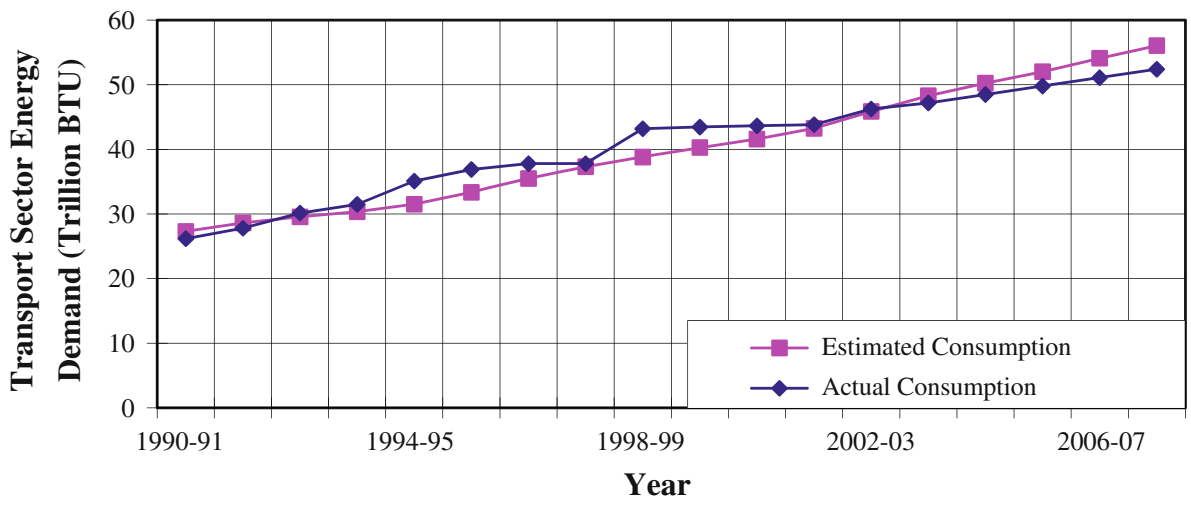

different levels. The study was conducted for the span of 25 years from 2005 to 2030 at 5-year interval.

Travel and energy demand assessment

We estimated base level travel demand on the basis of vehicle population, usage rate, fuel economy, and occupancy rate for passenger and loading rate for freight transportation. Because of unavailability of historic information, we forested travel demand using reported information on vehicle stock, vehicle kilometers travelled and occupancy rate as shown below (Eqs. 1, 2) following the framework suggested by Dhakal (2003). Future annual travel demand was calculated by multiplying estimated number of vehicles in each category with annual usage and occupancy information (Table 4) assuming that annual usage, occupancy rate, and loading rate would remain constant during study period.

Road passenger travel demand $(t)$

$$
=\sum_{i} \mathrm{~V}_{i}(t) \times \mathrm{VKT}_{i}(t) \times \text { occupancy rate }(t)
$$

Road freight transport demand $(t)$

$$
=\sum_{i} \mathrm{~V}_{i}(t) \times \mathrm{VKT}_{i}(t) \times \text { loading rate }(t)
$$

where $\mathrm{V}_{i}(t)$ is vehicle population and $\operatorname{VKT}_{i}(t)$ is average annual vehicle kilometer travelled by vehicle type $i$ in year $t$.
For analyzing fuel usage by different modes in alternate policy scenarios, corresponding modal demand was estimated by distributing aggregate demand among sub-sector level through modal share to provide estimates of travel demand for road, rail and waterways. Energy consumption by fuel type was estimated as follows (Eq. 3):

Fuel demand $(t)=\sum_{i} \operatorname{TVKT}_{i}(t) \times \mathrm{F}_{i j}(t)$

where $\operatorname{TVKT}_{i}(t)$ is annual total vehicle kilometer travelled by $i$ th type of vehicle and $\mathrm{F}_{i j}(t)$ is the fuel economy $(\mathrm{km} / \mathrm{l})$ of $j$ type fuel for vehicle $i$ in year $t$.

Information regarding vehicle's fuel efficiency in the country is summarized in Table 4. Due to lack of data on fuel efficiency trend in Bangladesh, outputs of relevant studies in other countries were examined and incorporated in analysis. Studies suggest that fuel efficiency improved by $15 \%$ between 1980 and 1995 but remained stagnant since then (ECMT 2003; ECMT/IEA 2005). Zachariadis (2006) suggested that during the period 2000-2030 fuel efficiency might increase by $3.8 \%$ resulting in annual average improvement of $0.126 \%$ in fuel consumption rate, which was incorporated in the analysis.

Data required for the analysis was collected from various secondary sources, which include reports published by Bangladesh Bureau of Statistics and Ministry of 
Communications of Government of Bangladesh. Information on registered vehicle, as reported in government statistics, does not consider volume of expired vehicles (BBS 2009). Vehicle ownership in many developing countries grew twice as fast as per-capita income during 1970-2002 (Dargay et al. 2007). Considering trend of income and vehicle ownership growth with energy scarcity, price escalation, and car usage restraining policy, it is reasonable to expect that Bangladesh will experience growth in vehicle ownership at least as rapid as its growth in per-capita income. As suggested by Storchmann (2005), depreciation time was assumed to be 25 years for passenger cars and 30 years for commercial vehicles. Although government recently banned vehicles older than 20 years from Dhaka City, it has not been implemented yet. Price elasticity of fuel demand is estimated to be -0.0311 for Bangladesh and considering level of fuel use it can be assumed to remain inelastic during the study period (Robert 1994).

For validation purpose, predicted road sector fuel usage was compared with the consumed amount reported by Bangladesh Bureau of Statistics (2009) for the period between 1990 and 2007. As depicted in Fig. 4, estimated volume generally agrees with reported consumption. There exist some deviations between the two values particularly during 90s. This might result from oil being smuggled out of the country because of price difference with neighboring countries. Government increased fuel price at different stages to adjust to international market price that reduced the difference gradually.

\section{Results and discussion}

Transport energy demand and its economic consequence

In 2005, when average market price of fuel was about $\$ 60$ / bbl and country's transport sector fuel demand was 1.7 million ton of oil equivalent (Mtoe), Bangladesh expended US $\$ 773$ million to import fuel for transport sector amounting to $1.37 \%$ of national GDP. Road sector fuel demand is expected to increase from 50 trillion BTU in 2004 to 220 trillion BTU in 2020 and about 440 trillion BTU in 2030 under Business-as-Usual (BAU) scenario. Diesel demand is projected to increase from 1.2 Mtoe in 2005 to 4 Mtoe in 2020 and more than 8 Mtoe in 2030. Moreover, as discussed previously, price of fuel is also expected to increase. Figure 5 summarizes the joint effect of increasing demand and price, assuming inelastic scenario. Increase of fuel price to $\$ 120 / \mathrm{bbl}$ will result in a situation where about $14 \%$ of country's GDP might be consumed for importing fuel to keep road sector running in 2030. As reported by the World Bank, oil price increase between December 2002 and April 2006 caused the economy and terms-of-trade to shrink by 1.2 and $2.9 \%$ of GDP respectively (World Bank 2006). Consequently, scenarios illustrated above may severely dent national development plans.

Alternative options for transport sector

Energy crisis is a global concern and its interaction with transport is an active field of research. Investigations conducted in this regard range widely from alternative fuel and vehicular technology to performance optimization and demand management options. Considering technical and economic constraints, many alternatives that are being pursued in developed countries might not be feasible in the context of Bangladesh. In limited scope of this study, impacts of few feasible alternatives are discussed below.

1. Compressed natural gas conversion: since 2002, government has been actively promoting the use of CNG as alternative fuel for transport vehicles. By 2005, all urban three wheeler para-transits were replaced by CNG based vehicles and about $50 \%$ of other motorized vehicles were converted to CNG. As shown in Fig. 6, due to conversion to CNG total imported fuel consumption may reduce to 5.6 Mtoe by the year 2030 saving about 5 billion dollars at fuel price of $\$ 120 / \mathrm{bbl}$. It is worthy to mention that although consumption of CNG as transport fuel may reduce economic burden in
Fig. 5 Effect of fuel price increase as percentage of GDP in Bangladesh

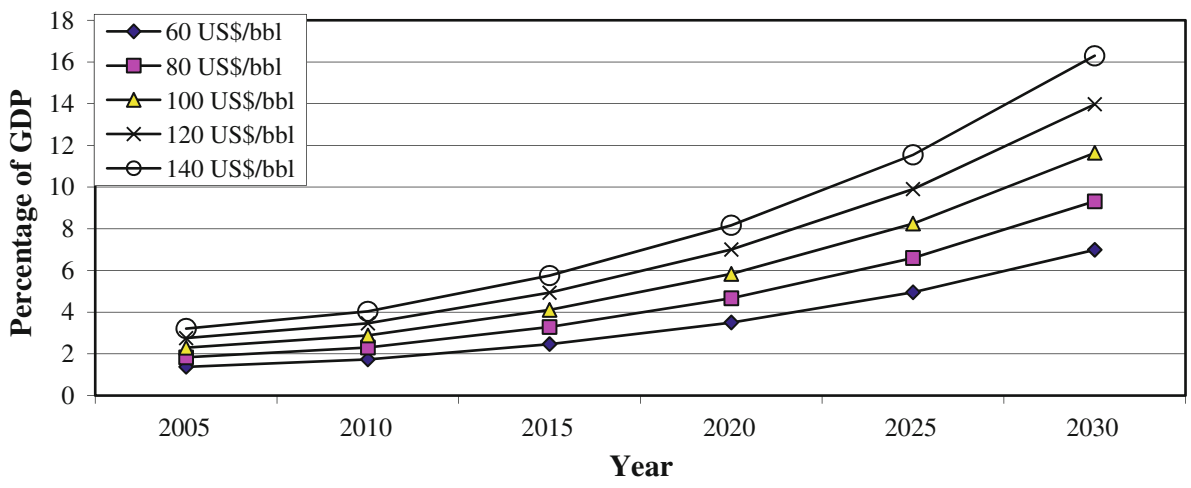


Fig. 6 Effect of policy options on transport sector energy demand

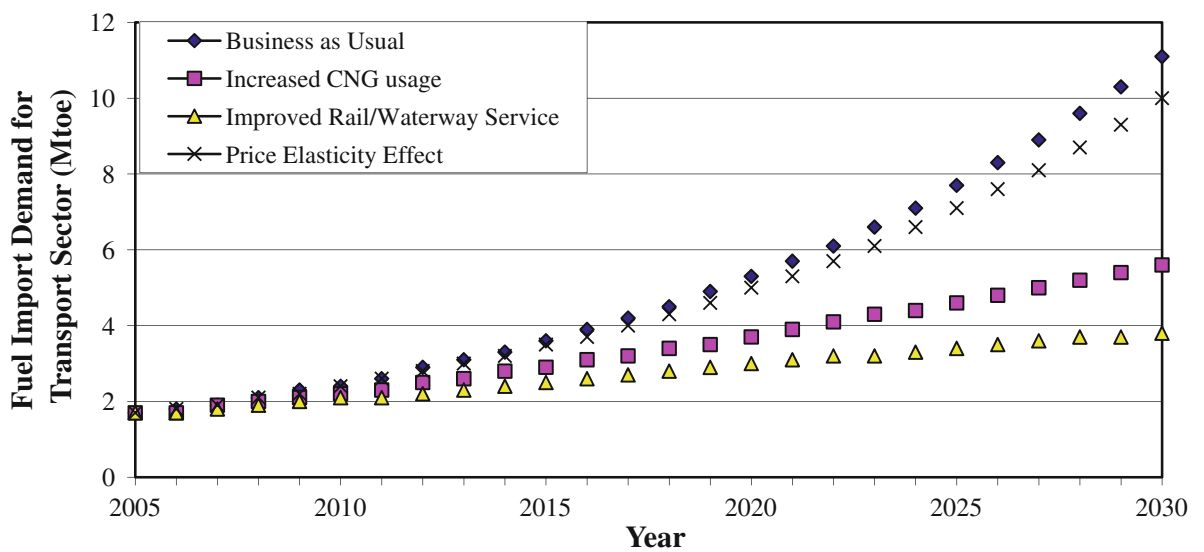

short term, policy makers should be concerned with its limited availability, international market price and opportunity cost. The country is already suffering from shortage of natural gas supply and contemplating gas import from neighboring countries.

2. Modal shift to rail transport system: flat terrain, almost square shaped geographical layout and radial travel demand pattern in Bangladesh makes it highly suitable for railway system. Unfortunately, it has been broadly neglected for decades resulting in demeaning its role in national transportation. Recently government has taken initiative to revitalize rail system which is more efficient with respect to energy and environmental considerations (Land Transport Policy of Bangladesh 2006). Analysis suggest that $30 \%$ diversion of modal share from road to rail, in addition to increased use of CNG in road vehicles, may reduce transport energy import demand to about 4 Mtoe in 2030 and result in cost reduction by about $10 \%$ of GDP. Electrification of rail system will also have a beneficial effect on petroleum imports as long as electricity is not produced from oil based generators. Meanwhile, it should be recognized that materialization of modal shift needs improvement in service quality which requires commensurate investment.

3. Modal shift to water transport system: Bangladesh is blessed with network of natural streams which caters for more than 10 and $30 \%$ of its passenger and freight transportation demand. The country possesses 5,968 and 3,600 $\mathrm{km}$ of navigable waterways during monsoon and dry seasons, respectively. River network of Bangladesh serves as natural drainage of the country, and it has been functioning as the major means of transportation in some areas especially in southern districts. Inland water transportation services are mostly provided by private sector. Appropriate planning and investment may further enhance its role in national transport system thereby reducing pressure on road network. Through investment for improvement of navigational and terminal facilities, about $10 \%$ in passenger and $20 \%$ in freight transport demand shift in modal share can be achieved which may result in reduction of energy demand by about 2 Mtoe in 2030 and import cost by $5 \%$ of GDP.

4. Price impact and gasoline subsidy: widespread government interventions in influencing domestic prices of petroleum products have had moderating effect on inflation and output growth. Many countries in the region, which include Bangladesh, China, India, Indonesia, Malaysia, Thailand, and Viet Nam, intervene administratively to set petroleum prices. However, oil price subsidies created significant fiscal burden on these countries besides inflating fuel demand. Also, oil subsidies have become fiscally unsustainable due to rapidly rising price. Government of Bangladesh should take initiative to eliminate fuel subsidy, and thereby rendering alternative options to be economically equitable. Assuming a long run price elasticity of -0.3 , impact of fuel price increase was assessed in LEAP framework as illustrated in Fig. 6 (Victoria Transport Policy Institute 2007). It shows that due to increase in fuel price, demand may reduce by about $9 \%$ as compared to BAU scenario. In 2008, when oil price reached the peak, government substantially increased the price and maintained it even after fall of oil price in international market.

\section{Conclusion}

Results of the study suggest that transport policy has significant implication on national energy demand scenario and economy. For the last three decades governments prioritized road transport system and consequently more than $80 \%$ of transport sector investment was routed to improvement of road network. This policy bias created modal share pattern dominated by road transport for both passenger and freight movement. Over dominance of road 
transport resulted in energy intensive transport system which became highly dependent on imported fuel. Reliance on imported fuel has made it vulnerable to the uncertainties of fuel supply and price in international market. In recent years, concerns about depleting amount of resources, uncertainties in international politics and increasing demand caused rapid increase of fuel price which resulted in crippling effect on the economy of Bangladesh. Fuel price is expected to increase further in future. Transport sector, which consumes about a quarter of aggregate national energy supply and half of imported fuel, has a significant role to play in this context. Currently about $2 \%$ of GDP is expended for importing energy required in transport sector. If the fuel price increases to $\$ 120 / \mathrm{bbl}$, by the year 2030 about $14 \%$ of national GDP will have to be expended in order to maintain mobility of country's transport system. Government is required to take adequate measure to reduce the share of road transport and its reliance on imported fuel. Enhanced use of alternate fuel like CNG can reduce the burden on imported fuel in the short run, but economic potential of utilizing $\mathrm{CNG}$ in other profitable ventures should also be considered. More sustainable solutions include prioritization of rail and water transportation system. Country's geographic suitability and environmental benefits make rail and water based system more favorable. Moreover, it is imperative to end subsidizing fuel and rationalize its usage.

Lastly, this study is primarily based on trend analysis and does not include issues like price elasticity of fuel demand, economic scenarios and change in the capacity and technology of vehicle. Moreover, it does not examine other possible options such as travel demand management, alternate fuels, and regulatory measures. The framework used in this study has been rather static in nature due to data limitations. Significance of the research may be enhanced by including dynamic interactions among demand, supply and price as well as environmental implications which will be done in future.

Acknowledgments The authors wish to thank Commonwealth Association UK for funding the research work and Roads and Highways Department, Ministry of Communications, Government of Bangladesh for their data support.

\section{References}

Balat M, Ayar G (2005) Biomass energy in the world, use of biomass and potential trends. Energy Sources 27:931-940

BBS (2009) Statistical year book of Bangladesh. Bureau of Statistics, Government of Bangladesh, Dhaka

Bose RK (1996) Energy demand and environmental implications in urban transport—case of Delhi. Atmos Environ 30(3):403-412

Dargay J, Gately D, Sommer M (2007) Vehicle ownership and income growth, worldwide: 1960-2030. Energy J 28(4):163-190
Dhakal S (2003) Implications of transport policies on energy and environment in Kathmandu valley, Nepal. Energy Policy 31: $1493-1507$

DTI (2001) Energy consumption in the UK 2001. Department of Trade and Industry, UK

ECMT (2003) Managing the fundamental drivers of transport demand. OECD Paris, France

ECMT/IEA (2005) Making cars more efficient-technology for real improvements on the road. IEA/OECD, Paris

Economic Review of Bangladesh (2009) Ministry of finance and economic affairs. GOB, Dhaka

EIA (2006) Short-term energy outlook. Energy information administration, US Department of Energy, Washington. www.eia.doe. gov/emeu/steo/pub/. Accessed April 2006

EIA (2007) International energy outlook 2007. Energy Information Administration, DOE/EIA-0383, US Department of Energy, Washington

European Commission (2004) Energy and transport: report 2000-2004. EC Directorate-General for Energy and Transport, Brussels

Faruque MA, Hossain MA, Alam MN, Begum KZ (2002) Energy forecast report: Bangladesh. Workshop on model South Asia energy forecast report, Kathmundu

Feiler G (2006) Global oil trends and their effect on the Middle East. Israel Aff 12(4):698-714

IIFC (2006) Draft coal policy, infrastructure investment facilities centre (IIFC). Ministry of Energy, Government of Bangladesh, Dhaka

Land Transport Policy of Bangladesh (2006) Ministry of communications. GOB, Dhaka

LEAP (2006) Long range energy alternatives planning system. User guide for LEAP 2006. Stockholm Environmental Institute (SEI-B), Boston Center, Tellus Institute, Boston

Miah MD, Kabir RRMS, Koike M, Akhter S, Shin MY (2010) Rural household energy consumption pattern in the disregarded villages of Bangladesh. Energy Policy 38(2):997-1003

NCHRP (1999) Economic trends and multimodal transportation requirements. Transportation Research Board, Washington (NCHRP report, issue 421)

NEP (2004) National energy policy. Ministry of Power, Energy and Mineral Resources, GOB, Dhaka

REP (2008) Renewable energy policy of Bangladesh. Ministry of Power, Energy and Mineral Resources, GOB, Dhaka

Rezki L, Brennand G (2002) Oil outlook to 2020. OPEC Rev 26(2):81-123

RHD (2005) Road user cost annual report for 2004-05. Roads and Highways Department, Ministry of Communications, Government of the People's Republic of Bangladesh, Bangladesh

Robert M (1994) Gasoline demand in developing countries. Energy J 15:143-155

Storchmann K (2005) Long-run gasoline demand for passenger cars: the role of income distribution. Energy Econ 27:25-58

UN-ESCAP (2005) Socio-economic policy brief, issue no. 2. United Nations, Bangkok, Thailand

Victoria Transport Policy Institute (2007) Transportation elasticities: how prices and other factors affect travel behavior. TDM encyclopedia. www.vtpi.org/elasticities.pdf. Accessed Mar 2007

Wadud Z, Dey HS, Kabir MA, Khan SI (2011) Modeling and forecasting natural gas demand in Bangladesh. Energy Policy 39(11):7372-7380

World Bank (2006) Global economic prospects 2006 (as of March 2007). http://web.worldbank.org/wbsite/external/extdec/extdec prospects/extgblprospectsapril. Accessed Mar 2007

Zachariadis T (2006) On the baseline evolution of automobile fuel economy in Europe. Energy Policy 34(14):1773-1785 